\title{
Quality of Life and Socioenvironmental Degradation in the Cantareira System Environmental Protected Area, SP, Brazil
}

\author{
Sônia Regina da Cal Seixas, ${ }^{1}$ João Luiz de Moraes Höeffel, ${ }^{2}$ \\ Michelle Renk, ${ }^{1}$ and Benedita Nazaré da Silva ${ }^{2}$ \\ ${ }^{1}$ NEPAM, Environmental Studies Center, Campinas State University, Rua dos Flamboyants, 155 Cidade Universitária Zeferino Vaz, \\ 13083-167 Campinas, SP, Brazil \\ ${ }^{2}$ Centre for Sustainability Studies, FAAT College (NES/FAAT), Estrada Municipal Juca Sanches, 1050 Boa Vista, \\ 12954-070 Atibaia, SP, Brazil
}

Correspondence should be addressed to João Luiz de Moraes Höeffel, jlhoeffel@gmail.com

Received 11 December 2011; Revised 7 March 2012; Accepted 3 June 2012

Academic Editor: Michelle Thompson-Fawcett

Copyright (C) 2012 Sônia Regina da Cal Seixas et al. This is an open access article distributed under the Creative Commons Attribution License, which permits unrestricted use, distribution, and reproduction in any medium, provided the original work is properly cited.

\begin{abstract}
Studies on quality of life can contribute to a better understanding of situations where socioenvironmental transformations are evident, from environmental, social, cultural, and political perspectives. This paper analyzes the quality of life of the inhabitants of the Moinho rural settlement in the context of the surrounding conditions of environmental degradation. Moinho is located in Nazaré Paulista municipality, which belongs to the Cantareira System Environmental Protected Area (Cantareira EPA), state of São Paulo, Brazil. The methodology used was based on secondary data collection and interviews with local residents. The results explore the interface between the transformation of land use and the growing change of rural life that are greatly influenced by expanding urban sprawl in the region. Over recent decades, changes in the production systems, substitution of agriculture crops, and the impacts of these variables on environmental health and water availability, as well as damage to the Municipal Human Development Index (HDI-M) of its municipalities, are indicators of the region's present social complexity. This study shows that an improvement in the quality of life has an intimate relationship with the creation of sustainable economic activities and the real participation of the local population in decision making processes.
\end{abstract}

\section{Introduction}

The last century experienced a global process of urbanization and industrialization that resulted in increased consumption and energy generation. This process created the foundations of modern society and resulted in unprecedented pressure on natural resources throughout the biomes of the planet [1-5].

In Brazil, studies show the existence of exploitive production activities in the remnants of the Atlantic Forest even in Environmental Protected Areas (EPAs).This can be seen in the case of the Cantareira System Environmental Protected Area, an area composed of 227,949 hectares and encompassing municipalities on the border between the states of São Paulo and Minas Gerais in southeast Brazil.

In the 1970s, this region's abundant water led to its being chosen for the creation of the Cantareira Water Supply
System that produces approximately $33 \mathrm{~m}^{3} / \mathrm{s}$ of potable water which goes to various parts of the Metropolitan Region of São Paulo $[6,7]$. The region has undergone several periods of economic activity that have transformed the landscape into a new urban and rural configuration [8].

There is a pressing need to understand the impact of this new configuration upon the quality of life of the inhabitants of the rural settlements of the Cantareira EPA. The analysis described in this paper focused on the settlement called Moinho, located in Nazaré Paulista, São Paulo, Brazil.

Based on data gathered in the region [7, 9-13], secondary data collection (IBGE, DATASUS, HDI-M) and interviews with local residents, this paper presents the interface between the transformation of land use and the growing change of rural life. These transformations are greatly influenced by expanding urban sprawl in all of the cities in the region. Over 
recent decades changes in production systems, substitution of agriculture crops, and the impacts of these variables on environmental health and water availability, as well as damage to the Municipal Human Development Index (HDI$\mathrm{M})$ of its municipalities, are indicators of the region's present social complexity.

\section{Quality of Life and Socioenvironmental Degradation}

The recognition of the relationship between quality of life and environmental problems is recent in contemporary discussion [14]. The human sciences and environmental sociology in particular have only recognized an intimate relationship between these two themes since the 1980s [15]. This has probably come about because of the effects that environmental degradation has imposed on the lives of populations in different regions of the planet [5].

The first signs of recognition occurred at World Conferences held in the United Kingdom and France during the 1980s, organized by the governments of these countries. These conferences although concerned with planetary environmental problems failed to implement broad actions, but were preparatory for the world summit in Rio in 1992. The environmental question had become a central theme in important worldwide discussions, and the idea of quality of life was relevant in this debate $[4,16-21]$.

On an international level, including researches in Brazil, this subject began to attract attention when the concept of quality of life associated with the environmental question became an approach to analyze modern society [22]. Initially there was mostly interest in the close relationship between quality of life and health. Later on, this strong interest in health issues was joined by a growing interest in urbanization and citizenship [15, 23-26].

In the second half of the 1990s, Barbosa took a different approach in her research on quality of life and environment when she introduced the idea of subjectivity and mental health. Initially this research was directed at urban populations in a few cities in the interior of São Paulo state [23]. She later expanded her research to other social groups that included traditional fishermen $[27,28]$ and rural population $[7,29]$.

In Latin-America, the connections between quality of life, subjectivity, and mental health were also present in the works of the authors Galtung [30], Montes and Leff [31], and Gallopín [32], and it is interesting that they focused their analysis on environment as a multifaceted category. Based on these reflections, Barbosa [33] stated that quality of life should be understood as occurring on three main axes. The first axis is concerned with meeting such basic needs as education, transportation, work, food, sanitation, health care, and so forth and access to them through efficient collective transportation and adequate salaries. The second axis deals with meeting the basic needs for culture, leisure, satisfactory friendships and intact family relationships, relationships with nature, and satisfying relationships at work. Finally, the third axis addressed ethical-political benefits and referred to the need for access to information about political participation and involvement in collective causes and participation in the local management of government and urban life $[23,33,34]$.

It is possible to understand quality of life as the sum of objective and subjective conditions in the everyday life of the individual. These conditions include the socioenvironmental transformations society undergoes on both a local and global level. In this daily struggle, the individual encounters answers to affirm or refute these transformations. The individual can politically legitimize day-to-day life or alienate himself/herself; construct healthy or pathological conditions of life. The concept of quality of life adopted here can contribute to a greater understanding of places and situations where socioenvironmental transformations are evident not only from the environmental point of view but also from the social, cultural, and political point of view as well [1,35-37].

\section{Socioenvironmental Transformation and Degradation in the Cantareira System EPA, São Paulo: Results and Discussion}

The Bragantina region is located in the northeastern part of the state of São Paulo and extends into the southern region of the State of Minas Gerais, Brazil (Figure 1). This region is remarkable both for its natural beauty and for the profound socioenvironmental transformations that occurred after the construction of the Cantareira Reservoir System, which began in 1965, and the duplication of the regional highways (Dom Pedro I and Fernão Dias) in the 1980s and 1990s [11].

Located in this region, the Cantareira System EPA was established by São Paulo State Law 10.111/1998 and, as seen in Figure 2, administratively and territorially encompasses the cities of Mairiporã, Atibaia, Nazaré Paulista, Piracaia, Joanópolis, Vargem, and Bragança Paulista, located in the State of São Paulo. This EPA also affects the cities of Toledo, Camanducaia, Extrema, and Itapeva located in Minas Gerais State [7]. This conservation area was created mainly for maintenance and improvement of water quality in the cities surrounding the Cantareira System's reservoirs.

Although ten years have passed since its creation, the absence of instruments to regulate the EPA and lack of a management plan is causing conflicts over land and water rights among various social actors. The first Management Council was established in 2009, and there is now a concrete possibility of a change to the previous scenario. However, this council is still new and its work to bring improvements to the socioenvironmental quality of this conservation area is not yet evident.

Easy access to this region by regional highways and its proximity to major urban centers are feeding a process of industrial, urban, and tourism expansion that is increasing regional socioenvironmental and cultural impacts. This reality has led to a call for studies, projects, and actions that make sustainable management of natural resources possible $[1,38]$. 


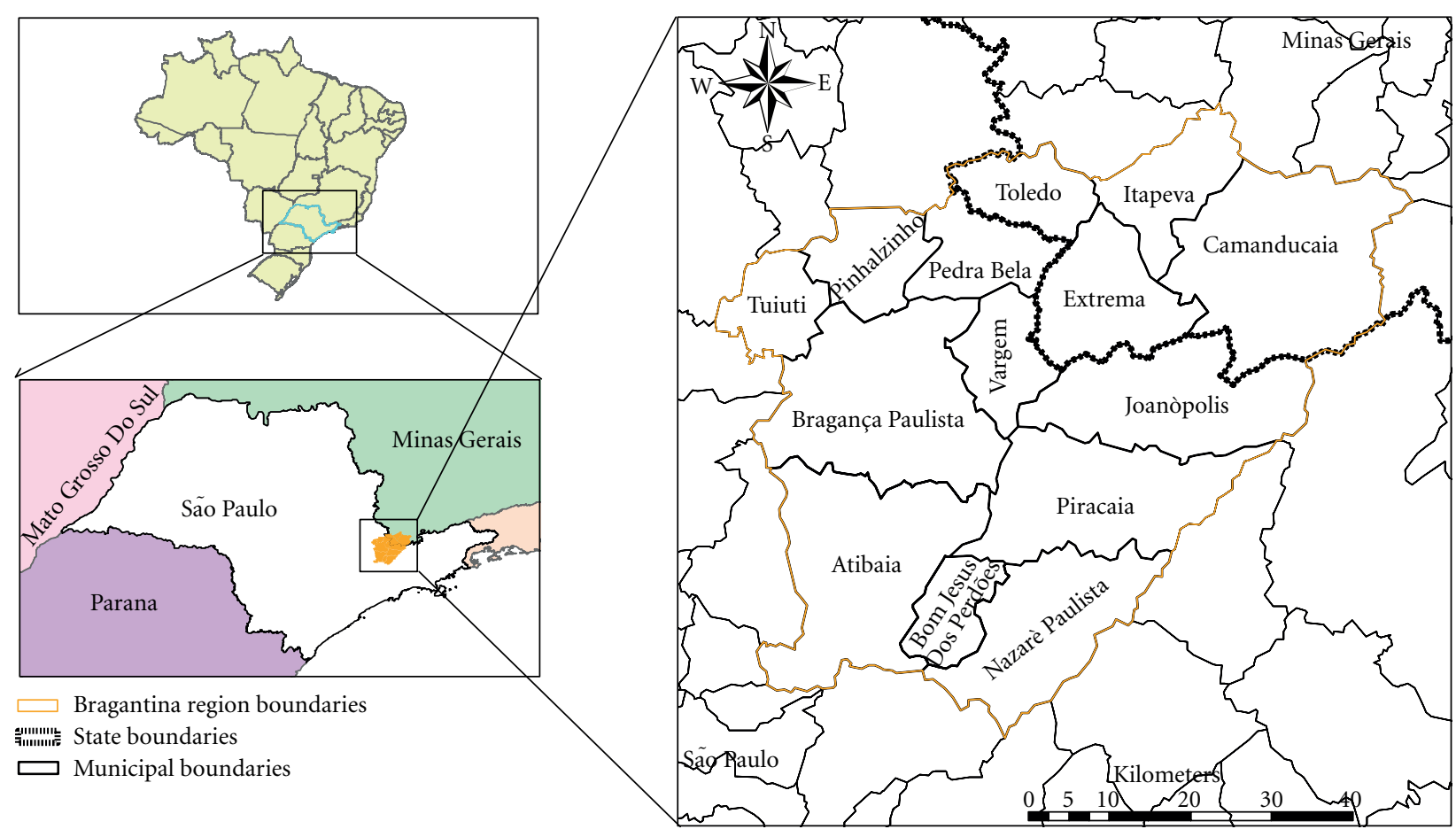

Figure 1: Location map of the bragantina region (São Paulo/Minas Gerais/Brazil). Source: Fábio Bueno de Lima, 2012.

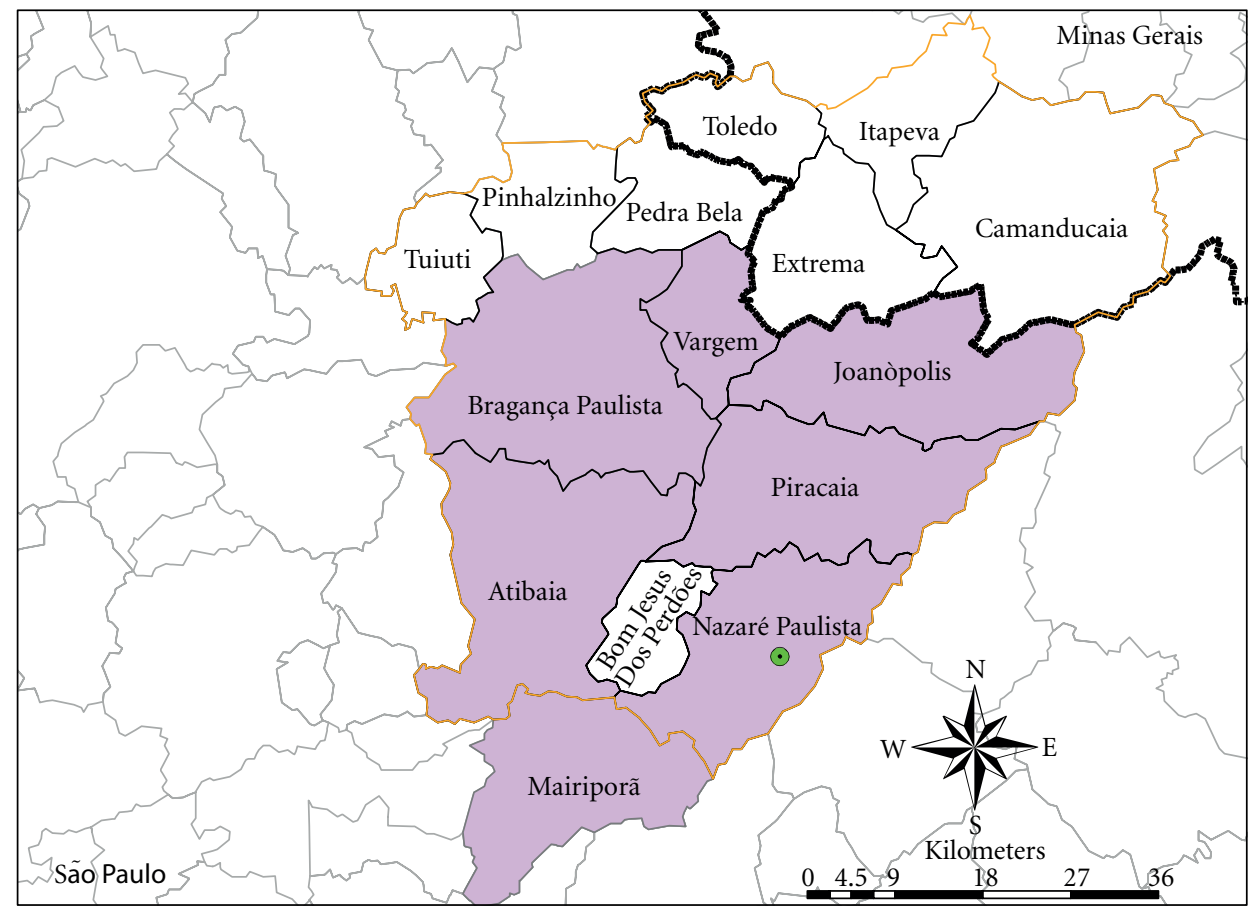

$\square$ Bragantina region boundaries

$\therefore$ 'r State boundaries

$\square$ Municipal boundaries

$\square$ Cantareira system EPA

$\odot$ Moinho neighborhood

Figure 2: Cantareira System EPA. Source: Fábio Bueno de Lima, 2012. 
Another important factor is that $70 \%$ of the Piracicaba River Basin river sources that supply water to western São Paulo State are located in the State of Minas Gerais, neighboring state to the state of São Paulo in its northern region, and this area is already suffering an accelerated process of transformation and diverse environmental impacts that may compromise the region's water resources.

Whately and Cunha [6] emphasize that a large part of the territory occupied by the five basins that make up the system have been altered by various kinds of human use and that areas covered by vegetation fundamental for production and purification of water occupy only $21 \%$ of the system's area. This data is alarming when considering the extreme importance of the locality for supplying water to the Metropolitan Region of São Paulo.

According to Barbosa and Höeffel [7], the region where the Cantareira Water Supply System is located required the flooding of large agricultural areas, forests, and homes and impacted mainly on the region's rural settlements. The flooding left countless farms, churches, schools, cemeteries and various types of local commerce underwater. Studies carried out by Höeffel et al. [13], Höeffel et al. [39], Höeffel [9], Fadini and Höeffel [11], Barbosa and Höeffel [7], Barbosa et al. [40], Whately and Cunha [6], and Rodrigues [41] show evidence of the fragility of public policies that attend fundamental socioenvironmental questions in the region.

Over the last few years, increases in restrictions and monitoring of activities that affect natural resources have become significant in areas regarded as strategic. One of the areas affected is the Cantareira System EPA. Environmental regulation has not been accompanied by local environmental educational programs and has, consequently, generated much conflict.

The environmental control system has restricted economic activities without providing the rural population with feasible environmentally appropriate alternatives. This divergence of objectives leaves no options for local communities and they persist in their traditional activities or in activities that bring in increased profits but cause significant environmental impacts. Reforestation with eucalyptus and the sale of their properties to real estate companies that end up subdividing the land into small parcels are some of these activities [13].

Urban sprawl and tourism development stimulated by the growth of the Metropolitan Region of São Paulo in the direction of this region and the creation of municipal policies for urban development have been intense and are evident in the proliferation of large condominiums that lack proper infrastructure [42].

This scenario reinforces the approach of Cabral and Souza [43], which emphasizes the need for a comprehensive regional discussion about the objectives, characteristics, and specifics of conservation units and for the promotion of significant participation not only from the public sector but from the local population as well in the management of socioenvironmental and political conflicts in order to implement an environmental protection area effectively [44].
TABLE 1: Water mains services (in \%) for the municipalities of the cantareira system EPA.

\begin{tabular}{lcc}
\hline Municipalities & \multicolumn{2}{c}{ Years } \\
\hline Atibaia & 1991 & 2000 \\
Bragança Paulista & 64.9 & 74.8 \\
Joanópolis & 89.5 & 94.6 \\
Mairiporã & 64.8 & 65.7 \\
Nazaré Paulista & 61.8 & 65.1 \\
Piracaia & 70.6 & 79.2 \\
Vargem & 59.9 & 67.9 \\
\hline
\end{tabular}

Source: Barbosa and Höeffel [7].

3.1. Water Supply, Environmental Health, and Human Development Index (HDI) in the Cantareira EPA. As we mentioned before, the study region is remarkable for its abundance of water resources and the Cantareira EPA was created to protect them and to improve the quality of the water supplied to the population. Although it was expected that access and distribution of potable water would not be a problem in the region, this is not the case in various municipalities, as can be verified in Table 1.

In 1991 in Piracaia, for example, the municipal water supply system met the needs of $59.92 \%$ of its population and the remaining $40.08 \%$ utilized wells or other systems. In 2000, Bragança Paulista met the needs of $94.58 \%$ of its population and Vargem $89.35 \%$, but the cities of Joanópolis, Piracaia, and Mairiporã maintained low supply levels, $65.75 \%, 67.92 \%$, and $65.06 \%$, respectively.

In 1991, the municipality of Atibaia met $64.90 \%$ of the water needs of the population, increasing to $74.80 \%$ in 2000 and Nazaré Paulista in 1991 met 70.59\% increasing to $79.20 \%$ in 2000 . Generally speaking, this data reveals problems in the supply of potable water to the region. This situation together with inordinate urban expansion and the absence of effective policies to protect water resources may significantly aggravate socioenvironmental problems.

Regarding Household Waste Collection (Table 2), for the period 1991 to 2000, there was a significant increase to this service and no municipality had an index below $80 \%$. Bragança Paulista and Vargem notably met $99 \%$ and $98.2 \%$ of their needs in 2000 . Despite a $19.54 \%$ and $16.48 \%$ increase in service during the period from 1991 to 2000, Joanópolis and Piracaia maintained indexes still considered low when compared to the level of service in the remaining municipalities. It is important to remember that these data mostly refer to urban areas and that in many rural areas waste collection is intermittent or nonexistent, leaving the population to dispose of refuse inappropriately.

The data analyzed in Table 3 reveal that Nazaré Paulista has a good basic health situation with $90 \%$ of household and commercial waste collected and removed to a landfill site. It should be noted that in previous years this volume reached $100 \%$ of the total. This data, however, must be tested with a more detailed analysis of the landfill and its installation and operation. As for sewage treatment, it can be verified that 
TABLE 2: Household waste collection (in \%) for the municipalities of the cantareira system EPA.

\begin{tabular}{lcc}
\hline Municipalities & \multicolumn{2}{c}{ Years } \\
\hline Atibaia & 1991 & 2000 \\
Bragança Paulista & 94.0 & 95.4 \\
Joanópolis & 66.2 & 99.0 \\
Mairiporã & 79.5 & 85.7 \\
Nazaré Paulista & 89.1 & 95.5 \\
Piracaia & 65.0 & 97.8 \\
Vargem & - & 81.5 \\
\hline
\end{tabular}

Source: Barbosa and Höeffel [7].

the municipality now treats $60 \%$ by means of a stabilization lake, although in previous years this volume was $100 \%$. This decrease is due to recent urban expansion of a new area known as Vicente Nunes and its distance from the treatment station.

The data presented in Table 4 reflects the profile of the municipalities in relation to the Municipal Human Development Index (HDI-M). (The HDI-M refers to the position occupied by the municipality in relation to other of the state of São Paulo with reference to human development, the municipality classified as number 1 is the one that presents the best performance. This indicator shows the municipality as a unit of analysis, based on longevity, education, and income, which participate as equal weights in the determination.) The municipalities in the Cantareira System EPA show expressive differences in relation to this indicator. Despite continuous improvement in all of the municipalities, only Bragança Paulista and Atibaia present HDI-M values of 0.820 and 0.819 . These are considered good in relation to the other 645 municipalities of the state of São Paulo, and in 2000 they occupied 59th and 66th place. The remaining municipalities in the study area are considered average, Joanópolis and Nazaré Paulista holding the worst places: 427th and 556th, respectively. The low per capita income, high rate of illiteracy, and lack of basic sanitation are the main factors that worsen the situation in these municipalities.

Data shows that environmental health and quality of life conditions are inadequate in the region; although recent data is not yet officially available, indications are that the yet to be published census of 2010 shows no significant change to this situation. Another important point to consider is that initiatives to dispose of solid residues adequately and experiments in recycling and the use of biomass for energy generation are not well documented in Brazil and a study area or pilot project is nonexistent.

We feel that knowledge of the strong impact caused by the construction of the reservoir and the widening of the highways is fundamental in order to understand this situation. In the words of Martins [45], large-scale economic projects, such as hydroelectric plants, highways, and colonization plans, promote great social and environmental impact on local populations.
This situation creates social and environmental problems highlighted in the processes of tourism, urban and industrial development that have been encouraged without adequate planning and that have altered the natural resources in this protected area and also brought economic, social, and cultural loss to the population that depends on them.

\section{The Impact of Socioenvironmental Degradation on Culture and the Rural Identity of the Settlement Known as Moinho Located in Nazaré Paulista, São Paulo State}

Moinho is located in the watershed of Moinho Creek in the Cantareira System EPA. It is a rural settlement made up of many small properties that serve as both primary and secondary residences. The secondary residences are used mainly for weekend leisure and tourism. According to estimates, in 2006, 550 people were considered permanent residents in Moinho and were distributed in 150 families. Due to its proximity to large cities such as São Paulo and Campinas, the region is highly attractive to tourists interested in water sports and a great number of hotels have been established in the region since the creation of the reservoir $[10,41]$.

The settlement is set in a mountainous relief, the fertility of the soil is considered low, and this makes it difficult to establish agriculture and even to raise cattle for milk or meat. With only $40.33 \%$ vegetation cover, a small part belonging to the Atlantic Forest and the rest secondary woods (including reforested areas of pine and eucalyptus used mainly for energy) and with $22.5 \mathrm{~km}^{2}$ of area flooded by the Atibainha Reservoir, Moinho has been the stage for a growing process of real estate speculation $[8,10]$.

The exaggerated advance of real estate enterprises, such as marinas, condominiums, and high-end residences, is contributing significantly to the degradation of the region's natural resources, in particular to Atlantic Forest remnants bordering the reservoir. A large part of the Atibainha Reservoir does not possess riparian woods, and this facilitates the erosion of its margins (shown below in Figure 3).

According to Almeida Jr.et al [12], the problem observed in Nazaré Paulista, especially in Moinho, is representative of a regional problem that is a real risk to the environment and to the population's quality of life. This problem calls for socioenvironmental regulation in order to avoid indelible consequences to both rural and urban life.

The authors point out that the absence of adequate environmental planning, zoning of activities, and effective regulation led to the almost total disappearance of agricultural and cattle-raising activities and only a few enterprises of this nature with some economic significance still exist causing social and environmental degradation to advance together, due to lack of soil management, improper disposal of residues, and promotion of rural exodus.

At the same time, the change in the organization of economic and sociocultural life in the settlement is also bound to global economic and technological factors. These 
TABLe 3: Sanitation in Nazaré Paulista/SP (waste treatment and sewage collection and treatment, in \%).

\begin{tabular}{lcccc}
\hline & & Years & \\
& 1995 & 1997 & 1999 & 2003 \\
\hline Waste treatment (household and commercial) (\%) & No data & 100 & 90 & No data \\
Sewage collection and treatment (\%) & 100 & 100 & 65 & 60 \\
\hline
\end{tabular}

Source: Barbosa and Höeffel [7].
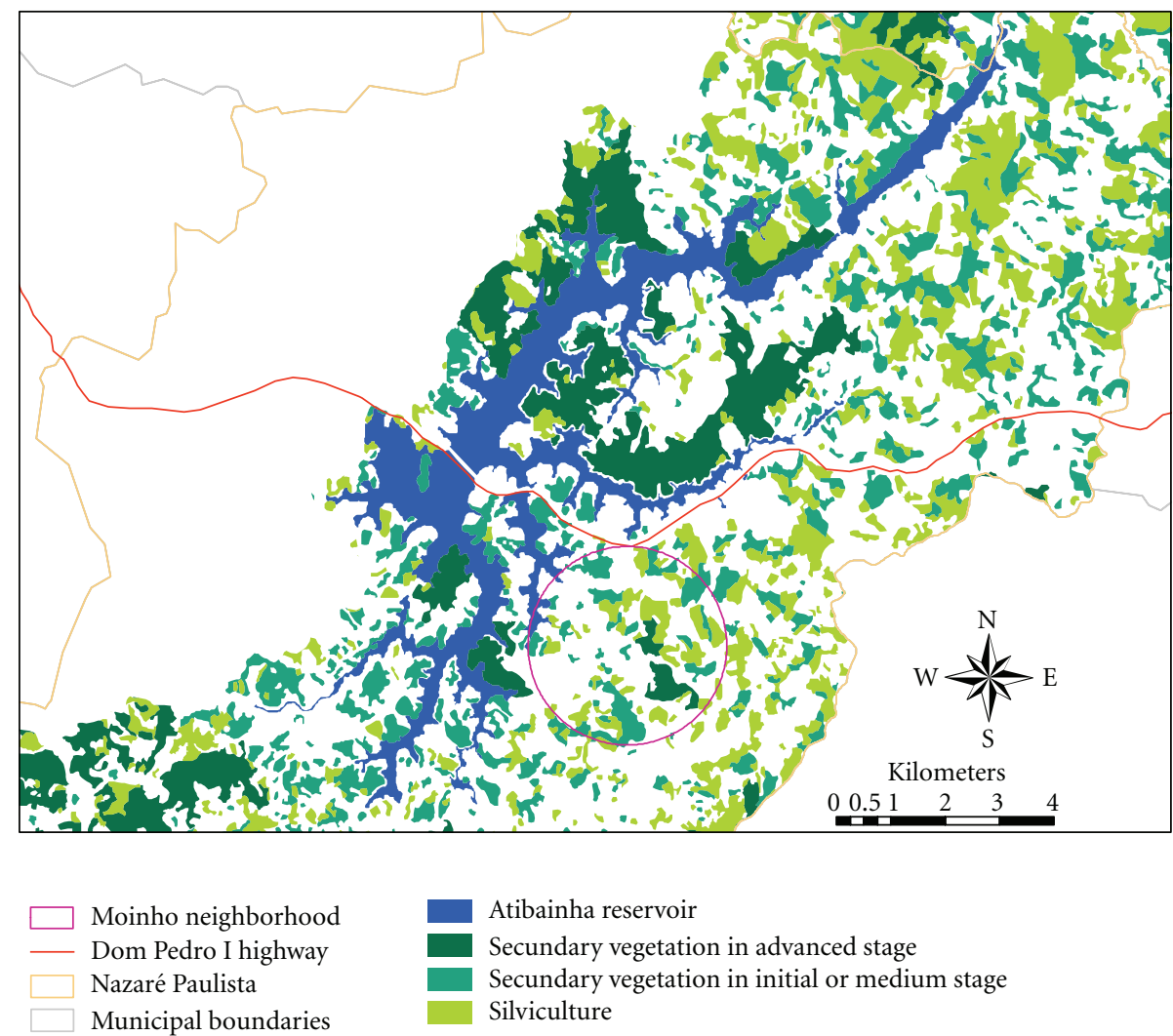

FIgURe 3: Native vegetation cover around the Atibainha Reservoir, Nazaré Paulista/SP. Source: Fábio Bueno de Lima (based on [6]), 2012.

Table 4: Municipal Human Development Index (HDI-M) for the municipalities of the cantareira system EPA.

\begin{tabular}{lccc}
\hline Municipalities & & Years & \\
& 1980 & 1991 & 2000 \\
\hline Atibaia & 0.698 & 0.777 & 0.819 \\
Bragança Paulista & 0.695 & 0.768 & 0.820 \\
Joanópolis & 0.657 & 0.717 & 0.766 \\
Mairiporã & 0.704 & 0.747 & 0.803 \\
Nazaré Paulista & 0.576 & 0.675 & 0.746 \\
Piracaia & 0.681 & 0.750 & 0.792 \\
Vargem & - & - & 0.782 \\
\hline
\end{tabular}

Source: Barbosa and Höeffel [7].

factors are allied or made explicit by the presence of new residents who offer other alternatives for income aside from rural production, introducing a form of life in which rural work becomes less attractive.
Consequently, it cannot be denied that the present model of development not only changed the environment but also modified social connections amongst neighbors that had existed for generations [12]. It is believed that these aspects are subtle indicators of alterations to the daily reality of the residents of Moinho and of the fragility of the public policies in effect for this region.

Therefore, to understand the reality in the Cantareira System EPA better, it is important to comprehend the manner in which the socioenvironmental changes interfere with the culture and identity of its inhabitants and that the varying notions of rural and rurality all lead us to recall a proximity with nature: the soil, the land, and the ecosystem. Rurality in the material production of life and within the social sphere with its subjectivities and sensibilities-and as social representation of these areas-cannot be understood without recognizing this proximity.

Using different approaches, some authors $[46,47] \mathrm{em}-$ phasize rural as a particular arrangement in space and social life implicit in the contours (the ecosystemic space), in the 
specificities (the place where one lives), and in representations (the place where one sees and speaks). In favor of the recognition of rural in contemporary life and based on the debate in advanced societies, Wanderley [48] takes the position of rural as a unique space and collective player and emphasizes parts of this debate (rurality as historic construction, rural as a diversified space, rural development as a new institutional commitment, and the emergence of a new rurality); these aspects allow us to identify various redefinitions of rural, new players, and new disputes.

Carneiro [49], Paula [50], and Rodrigues [47] look at the problem of rurality as new identities under construction, postulating rurality as the expression of new country-city relationships. Based on these studies, contemporary rurality can be interpreted as a postmodernization of agriculture (in the French case) and an incomplete modernization or interrupted and segmented (more like the Brazilian case). In both cases, these situations are shaped by a revalorization of nature through various and complex processes that configure a contemporary urbanity that revalorizes life in the country [47].

In general, rurality refers to the inhabitants' specific relationship with nature and to the common knowledge generated by this relationship and strengthened by experience and by direct communication. The connections between the notions of rural and social identity are what generate talk of rurality. At the same time, the interface between rurality and nature instigates discussions on territoriality and promotes questioning on the existence and pertinence of the concepts of territorialities and ruralities in Moinho.

In this context, it makes sense to ask: is there still a rural to speak of which generates rural identities and actors in Moinho? In this sense, the recognition of the socioenvironmental problems that the region faces and especially of the transformations which rural neighborhoods have undergone will lead to the real possibility of answering this question and helping its inhabitants to seek a better quality of life that results in actual improvements.

\section{Final Considerations}

Articulation of sustainable development proposals that are compatible with the socioenvironmental and cultural characteristics of the region studied not only demands an understanding of regional reality but also demands an understanding of the social identity dynamics of the population. The formulation and establishment of an appropriate management plan for the Cantareira System EPA is a reality that calls for participation from all areas of society, especially from local government institutions in the region. There is also a need to involve other municipalities within this EPA and not only those that directly benefit from its natural resources, especially water resources.

In this way, efforts made to consolidate the concept of interdisciplinarity and the effective involvement of researchers in the constitution of the recently established Management Council have made it possible to analyze and recognize the socioenvironmental complexity of the area under study and allow a greater involvement of the community, to the extent that civil society can participate and influence the direction of diverse activities that can be developed in the region with an environmental sustainability approach.

Due to the recent Brazilian history where popular participation was suspended during the period from 1964 to the mid-1980s, it is believed that this process is still long and slow but is already present, especially when we consider the directions that the Environmental Law imposes at the present moment.

As our work has a strong component of community involvement through concrete practices of environmental education and training courses in sustainable activities for the local groups, we believe we have contributed through the activities undertaken for the formation of an environmental consciousness that is beginning to impose itself on the rural neighborhood of Moinho and that could be extended to the larger community as the members take more responsibility for its direction.

The data analyzed on the municipality in which the Moinho neighborhood is situated considered the following aspects: mains water supply; household waste collection; waste treatment and sewage collection and treatment, and HDI-M for all the municipalities of Cantareira APA and showed that this analysis of indicators strengthens the idea that improvement in the quality of life has an intimate relationship with the creation of sustainable economic activities in the region and the contributions made by increased planning capacity and local and regional participation.

The three axes of analytical support for the concept of quality of life mentioned in this paper are evidenced in the case study setting in the following ways. The recognition that the community members have to meet (1) their basic needs; (2) their complementary needs of culture and adequate relations with family, nature, and labor; (3) the ethical-political dimensions of access to information about political participation, involvement in collective causes and in the local management of government and urban life. Through the data obtained in this work and from work done previously $[7-9,12,13,39,40]$, we believe that the real participation of the local population in decision making processes and in the construction of an identity that is recognized by the inhabitants themselves, informed by their subjective and objective realities, is essential.

\section{Acknowledgment}

The authors would like to thank the state of São Paulo Research Foundation (FAPESP) for the financial supportprocess 2006/60366-5.

\section{References}

[1] G. Evans and S. Cohen, "Environmental stress," in Handbook of Environmental Psychology, D. Stokols and I. Altman, Eds., vol. 1, pp. 571-610, John Wiley \& Sons, New York, NY, USA, 1987. 
[2] D. Banister, S. Watson, and C. Wood, "Sustainable cities: transport, energy, and urban form," Environment and Planning B, vol. 24 , no. 1, pp. 125-143, 1997.

[3] D. Hogan, "Um breve perfil ambiental do estado de São Paulo," in Migração e Ambiente em São Paulo: Aspectos Relevantes da Dinâmica Recente, D. Hogan, J. M. P. Cunha, R. Baeninger, and R. L. Carmo, Eds., pp. 275-381, Nepo/Unicamp, Campinas, Brasil, 2000.

[4] P. Hall, "Sustainable cities or town cramming," in Planning For a Sustainable Future, A. Layard, S. Davoudi, and S. Batty, Eds., pp. 101-114, E \& FN Spon, London, UK, 2001.

[5] P. Howley, M. Scott, and D. Redmond, "Sustainability versus liveability: an investigation of neighbourhood satisfaction," Journal of Environmental Planning and Management, vol. 52, no. 6, pp. 847-864, 2009.

[6] M. Whately and P. Cunha, Cantareira 2006: Um Olhar Sobre o Maior Manancial de Água da Região Metropolitana de São Paulo, Instituto Socioambiental, São Paulo, Brasil, 2007.

[7] S. R. C. S. Barbosa and J. L. M. Höeffel, "Qualidade de vida e complexidade social na APA Cantareira," SP: Um Estudo Sobre Degradação Socioambiental E Subjetividade", Relatório Científico, FAPESP, Campinas, Brasil, 2008.

[8] J. L. Hoeffel, A. A. B. Fadini, M. K. Machado, and J. C. Reis, "Percepção ambiental e conflitos de uso de recursos naturaisum estudo na APA do Sistema Cantareira, São Paulo, Brasil," in Anais do III Encontro da ANPPAS(ANPPAS '06), pp. 1-15, Campinas, Brasil, 2006.

[9] J. L. M. Höeffel, "Concepções sobre a natureza e sustentabilidade. Um estudo sobre percepção ambiental na bacia hidrográfica do Rio Atibainha," Nazaré Paulista/SP, Relatório de Pesquisa de Pós-DoutoradoProcesso CNPq n 151135/02-9 (NV), Bragança Paulista, Brasil, 2005.

[10] J. L. M. Höeffel, “Trajetórias do Jaguary. Unidades de Conservação, Percepção Ambiental e Turismo. Um estudo na APA do Sistema Cantareira," Relatório Final FAPESP 2003/08432-5, Bragança Paulista, Brasil, 2006.

[11] A. A. B. Fadini and J. L. M. Höeffel, "Mulheres da APA Cantareira - Reflexos da Construção do Sistema Cantareira na identidade e no modo de vida local," Relatório Parcial FAPESP, Bragança Paulista, Brasil, 2008.

[12] A. Almeida Jr., J. L. M. Höeffel, and O. Queda, A Propriedade Rural Como Símbolo, Hucitec, São Paulo, Brasil, 2008.

[13] J. L. Höeffel, A. A. B. Fadini, and S. R. C. Seixas, Sustentabilidade, Qualidade de Vida e Identidade Local, SP e Fernão Dias, MG, RiMa, São Carlos, Brasil, 2010.

[14] F. H. Buttel, "Sociologia ambiental, qualidade ambiental e qualidade de vida: algumas observações teóricas," in Qualidade de Vida \& Riscos Ambientais, S. Herculano, M. F. S. Porto, and C. M. Freitas, Eds., pp. 29-48, EDUFF, Niteroi, Brasil, 2000.

[15] A. Souza, Qualidade de Vida Urbana, Zahar, Rio de Janeiro, Brasil, 1984.

[16] F. H. Buttel, "Environmental and resource sociology: theoretical issues and opportunities for synthesis," Rural Sociology, vol. 61, no. 1, pp. 56-76, 1996.

[17] L. Brown, C. Flavin, and S. Postel, "O Planejamento de uma sociedade sustentável," in Salve o Planeta! Qualidade de Vida-1990/Worldwatch Institute, L. Brown, Ed., Globo Rio de Janeiro, Brasil, 1990.

[18] U. Beck, Ecological Enlightenment-Essays on the Politics of the Risk Society, Prometheus Book, New York, NY, USA, 1995.

[19] U. Beck, The Reinvention of Politics, Polity Press, Cambridge, UK, 1999.
[20] F. H. Buttel, "Ecological modernization as social theory," Geoforum, vol. 31, no. 1, pp. 57-65, 2000.

[21] J. A. Hannigan, Environmental Sociology, Routledge, New York, NY, USA, 2006.

[22] L. Brown, Salve o Planeta! Qualidade de Vida-1990/ Worldwatch Institute, Globo Rio de Janeiro, Brasil, 1990.

[23] S. R. C. S. Barbosa, Qualidade de vida e suas metáforas. Uma reflexão socioambiental, tese de doutorado em ciências sociais [Tese de Doutorado], Instituto de Filosofia e Ciências Humanas-Universidade Estadual de Campinas, São Paulo, Brasil, 1996.

[24] R. L. Carmo and População, Meio qmbiente e qualidade de vida: o caso de Campinas (1970-1991), em sociologia [Dissertação de mestrado], Instituto de Filosofia e Ciências Humanas, Universidade Estadual de Campinas, São Paulo, Brasil.

[25] A. C. Leal, Meio ambiente e urbanização na microbacia do areia branca-campinas, são paulo, de geociências e meio ambiente [Dissertação de Mestrado em Geociências/Área], Instituto de Geociências e Ciências Aplicadas, Universidade Estadual Paulista, São Paulo, Brasil, 1995.

[26] J. Matavele, Ecologia e qualidade de vida: o caso da favela Vila Nogueira (Campinas, SP), em Ecologia [Dissertação de Mestrado], Instituto de Biologia, Universidade Estadual de Campinas, São Paulo, Brasil, 1992.

[27] S. R. C. S. Barbosa, "Identidade social e dores da alma entre pescadores artesanais em Itaipu, Rio de Janeiro," Ambiente e Sociedade, vol. 7, no. 1, pp. 107-131, 2004.

[28] S. R. C. S. Barbosa, "Subjetividade e complexidade social: contribuições ao estudo da depressão," Physis, vol. 16, no. 1, pp. 317-350, 2006.

[29] S. R. C. S. Barbosa and J. L. M. Höeffel, "Qualidade de vida e complexidade social na APA Cantareira, SP: um estudo sobre degradação socioambiental e subjetividade," Relatório Científico FAPESP, Campinas, Brasil, 2009.

[30] J. Galtung, "Development, environment and technologytowards a technology for self-reliance," in Proceedings of the United Nations Conference on Trade and Development, Geneva, Switzerland, 1979.

[31] J. M. Montes and E. Leff, "Perspectivas ambientais del desarrollo del conocimiento," in Problemas del Conocimiento y a Perspectiva Ambiental del Desarrollo, E. Leff, Ed., pp. 1-26, Siglo Veintiuno México, 1986.

[32] G. Gallopín, "Ecologia y Ambiente," in Los Problemas del Conocimiento y a Perspectiva Ambiental del Desarrollo, E. Leff, Ed., pp. 88-130, Siglo Veintiuno Mexico, 1986.

[33] S. R. C. S. Barbosa, "Qualidade de vida e necessidades sentidas: uma aproximação teórica," Humanitas, vol. 1, pp. 15-38, 1998.

[34] S. R. C. S. Barbosa, "Qualidade de vida e risco na teoria social latino-americana: algumas considerações sobre o caso brasileiro," in Anais X Congresso Luso-Afro-Brasileiro de Ciências Sociais, pp. 1-13, Braga, Portugal, 2009.

[35] M. C. S. Minayo, Z. M. A. Hartz, and P. M. Buss, "Qualidade de vida e saúde: um debate necessário," Ciência \& Saúde Coletiva, vol. 5, no. 1, pp. 7-18, 2000.

[36] M. Pacione, "Urban environmental quality and human wellbeing-a social geographical perspective," Landscape and Urban Planning, vol. 65, no. 1-2, pp. 19-30, 2003.

[37] E. M. F. Seidl and C. M. L. Zannon, "Qualidade de vida e saúde: aspectos conceituais e metodológicos," Cadernos de Sau'de Pu'blica, vol. 20, no. 2, pp. 580-588, 2004. 
[38] CBH-PCJ, "Plano da Bacia Hidrográfica 2000-2003. Comitê de Bacias Hidrográficas-Piracicaba, Capivari e Jundiaí,” 2003, http://www.comitepcj.sp.gov.br/.

[39] J. L. M. Höeffel, M. K. Machado, A. A. B. Fadini, and F. Lima, "Concepções e percepções da natureza na Área de Proteção Ambiental do Sistema Cantareira," in Anais do IV Congresso Brasileiro de Unidades de Conservação, vol. 1, pp. 346-356, Fundação O Boticário de Proteção à Natureza, Curitiba, Brasil.

[40] S. R. C. S. Barbosa, J. L. M. Hoeffel, S. B. Cintra et al., "Condições socioambientais e qualidade de vida na APA Cantareira, SP: uma abordagem preliminar dos municípios de Vargem e Nazaré Paulista," in Anais IV Encontro Nacional da ANPPAS,, pp. 1-30, Brasília, Brasil, 2008.

[41] C. M. C. Rodrigues, Águas aos Olhos de Santa Luzia: Um Estudo de memória sobre o Deslocamento Compulsório de Sitiantes em Nazaré Paulista (SP), UNICAMP, Campinas, Brasil, 1999.

[42] J. L. Höeffel, A. A. B. Fadini, and C. F. S. Suarez, "The nature we all want-influences of São Paulo metropolis on tourism development in the bragantina region, São Paulo, Brazil," Tourism and Hospitality Planning \& Development, vol. 6, no. 3, pp. 191-205, 2009.

[43] N. Cabral and M. Souza, Área de Proteção Ambiental: Planejamento e Gestão, RIMA, São Carlos, Brasil, 2002.

[44] M. K. Machado, J. C. Reis, A. A. B. Fadini, J. L. Hoeffel, and F. B. Lima, "Moinho d'água: educação ambiental, participação e atuação comunitária," in Sustentabilidade, Qualidade de Vida e Identidade Local. Olhares sobre as APAs Cantareira, SP e Fernão Dias, MG, J. L. Hoeffel, A. A. B. Fadini, and S. R. C. Seixas, Eds., pp. 149-163, RiMa, São Carlos, Brasil, 2010.

[45] J. S. Martins, A Chegada do Estranho, Hucitec, São Paulo, Brasil, 1993.

[46] B. S. Santos, A Globalização e as Ciências Sociais, Cortez, São Paulo, Brasil, 2002.

[47] V. L. G. S. Rodrigues, Urbanização e Ruralidade. Os condomínios e os Conselhos de Desenvolvimento Municipal, MDA, Brasília, Brasil, 2009.

[48] M. N. B. Wanderley, "A emergência de uma nova ruralidade nas sociedades avançadas-o "rural" como espaço singular e ator coletivo," Estudos Sociedade e Agricultura, vol. 15, pp. 87$145,2000$.

[49] M. J. Carneiro, "Ruralidade: novas identidades em construção," Estudos Sociedade e Agricultura, vol. 11, pp. 53-75, 1998.

[50] S. G. Paula, O campo na cidade: esportes country e ruralidade estetizada [Tese de doutorado], IUPERJ, Rio de Janeiro, Brasil, 1999. 


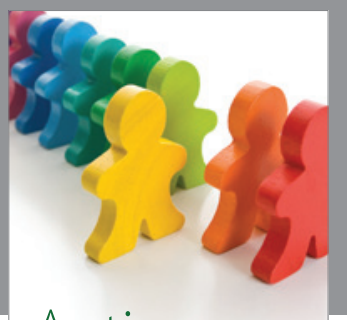

Autism

Research and Treatment
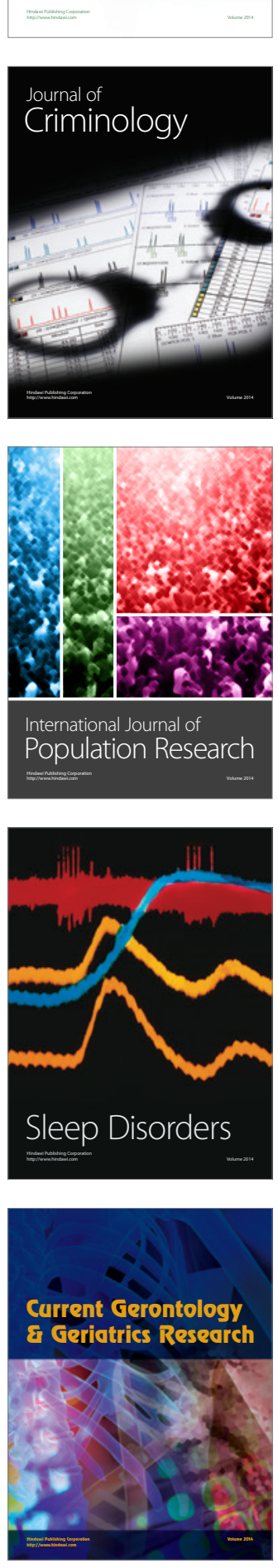
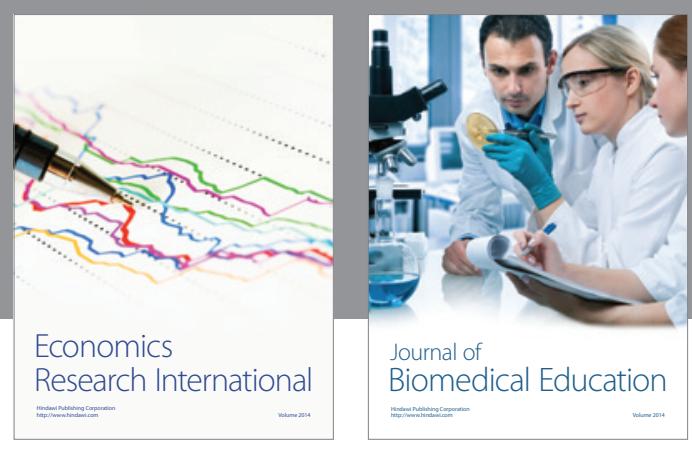

Journal of

Biomedical Education

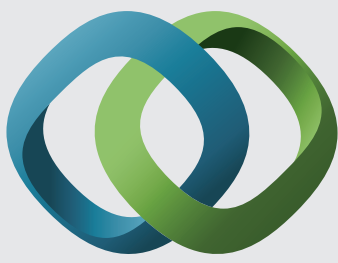

\section{Hindawi}

Submit your manuscripts at

http://www.hindawi.com
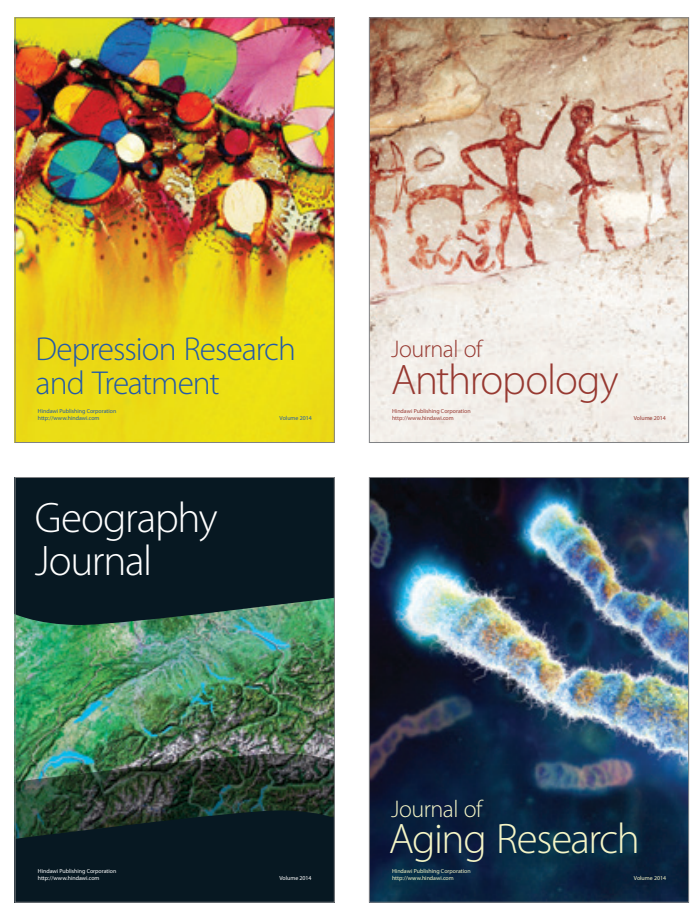

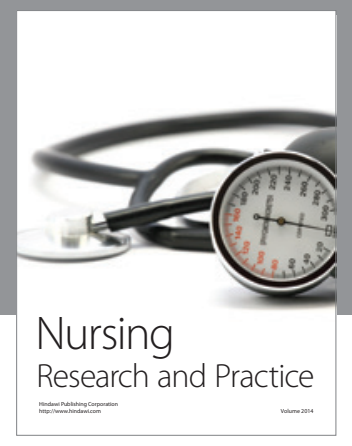

Nursing

Research and Practice

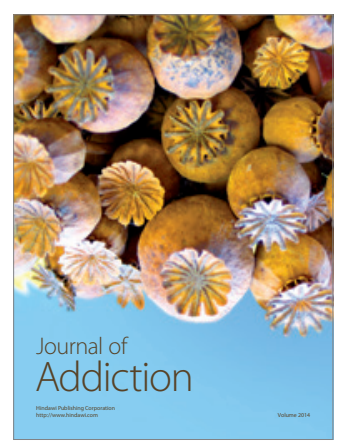

Child Development

Research

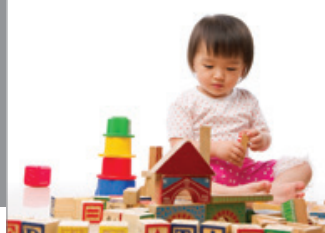

迥
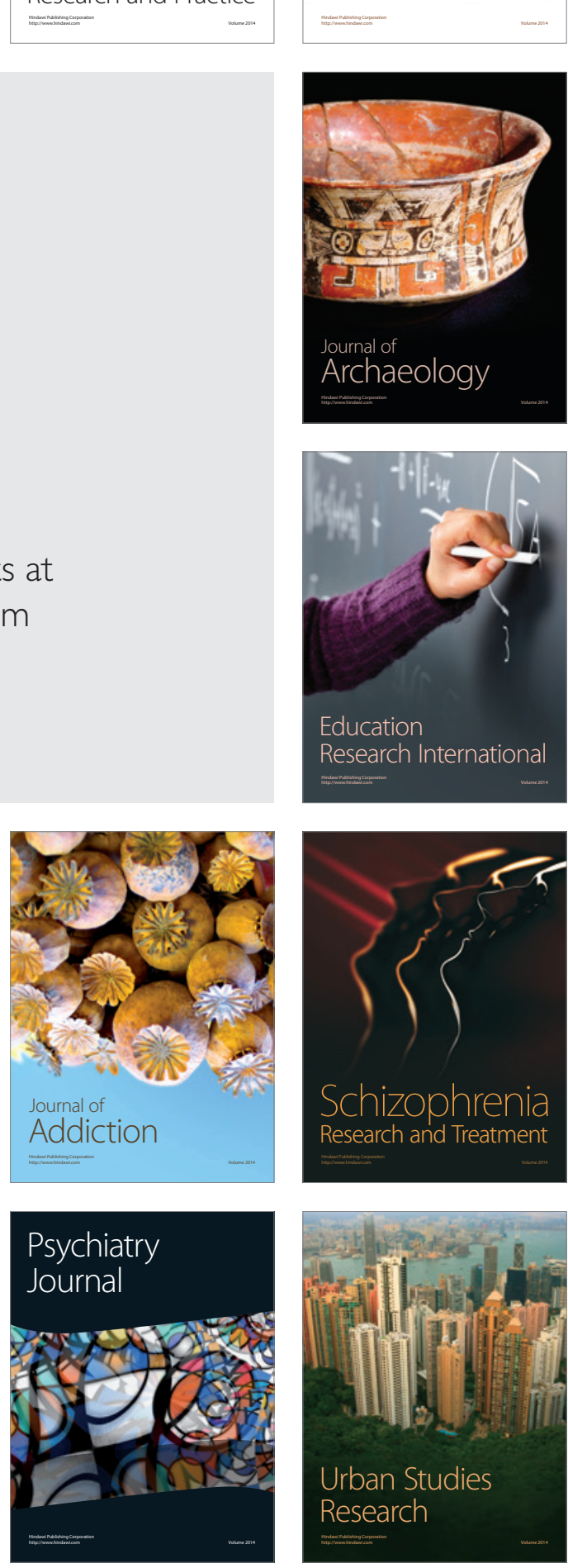